\title{
Process modeling of the nickel and iron reduction from oxide melts by converted natural gas
}

\author{
(C) Alexander S. Vusikhis, ${ }^{1+}$ Leopold I. Leontiyev, ${ }^{1 *}$ \\ Victor P. Chentsov, ${ }^{1}$ and Evgeny N. Selivanov ${ }^{1}$ \\ Institute of Metallurgy. Ural Branch of the RAS. Amundsen St., 101. Yekaterinburg, 620016. Russia. \\ Phone:+7 (343) 232-91-01.E-mail:pcmlab@mail.ru
}

\begin{abstract}
*Supervising author; ${ }^{+}$Corresponding author Keywords: methodology, thermodynamic modeling, kinetics, recovery, gas, bubbling, multicomponent oxide melt, iron, nickel.
\end{abstract}

\begin{abstract}
The converted natural gas using possibility to reduce iron and nickel from oxide melts in bubbled layer has been considered. The thermodynamic modeling technique has been applied to describe the kinetic features of the multicomponent oxide melts interaction processes with various compositions reducing gases.

Various types of conversion is used to obtain it (oxygen, steam, carbon dioxide) are considered. Influence of the natural gas/oxidizer gas ratio and the temperatures at which the conversion is carried out to the converted gases compositions is estimated.

It is shown that temperature increase from 1725 to $2273 \mathrm{~K}$ has little effect to the converted gases compositions. The hydrogen concentration in the products of oxygen conversion at $\mathrm{CH}_{4} / \mathrm{O}_{2}=2$ is $66.5 \%$; steam $\left(\mathrm{CH}_{4} / \mathrm{H}_{2} \mathrm{O}=1\right)$ is $75.0 \%$; carbon dioxide $\left(\mathrm{CH}_{4} / \mathrm{CO}_{2}=1\right)$ is $49.9 \%$ (the rest is $\mathrm{CO}$ ), respectively. Oxidant addition leads to $\mathrm{CO}_{2}$ and water vapor appearance in the mixture.

Bubbling kinetics is described by means of thermodynamic calculation. Reducing gas content and quantity (injected in oxide melt) affect to it properties is considered. The melt content changing, elements reduction degree, oxide and metal phases mass ratio, equilibrium contents of exhaust gases, etc are analyzed on this base. As was obtained, Nickel oxide residual content in the final melt have been decreasing to $0.03 \%$ and Nickel share in the ferronickel (formed in reducing process) is $70 \%$ in the case of oxidant absent. Residual $\mathrm{NiO}$ content in the oxide melt is higher, and degree of reduction is less in the presence of $\mathrm{CO}_{2}$ and $\mathrm{H}_{2} \mathrm{O}$. The results obtained allow us to predict the metals reduction process parameters in the oxide systems melt babbling treatment. It has been found that the most efficient gas is steam reformed.
\end{abstract}

\section{References}

[1] I.D. Reznik, G.P. Yermakov, Ya.M. Shneerson. Nickel. Moscow: LLC Science and Technology. 2001. Vol.2. 468p. (russian)

[2] L.Sh. Tsemekhman, L.B. Tsimbulov. Modern problems of pyrometallurgical processing of oxidized nickel ores in Russia. Non-ferrous metals. 2016. No.11. P.38-44. (russian)

[3] L.I. Leontiev, N.A. Vatolin, S.V. Shavrin, N.S. Shumakov. Pyrometallurgical processing of complex ores. Moscow: Metallurgy. 1997. 432p. (russian)

[4] A.S. Vusikhis, L.I. Leontiyev, V.P. Chentsov, and E.N. Selivanov. Modeling of the gas reduction of metals process from multi-component oxide melt in the bubbled layer. Butlerov Communications. 2018. Vol.55. No.7. P.58-63. DOI: 10.37952/ROI-jbc-01/18-55-7-58

[5] A.S. Vusikhis, L.I. Leontyev, D.Z. Kudinov, E.N. Selivanov. Thermodynamic modeling of nickel and iron reduction from a multicomponent silicate melt during bubbling. Message 1. A reducing agent is a mixture of CO-CO ${ }_{2}$. News of universities. Ferrous metallurgy. 2018. Vol.61. No.9. P.731-736. (russian)

[6] A.S. Vusikhis, L.I. Leontyev, D.Z. Kudinov, E.N. Selivanov. Thermodynamic modeling of nickel and iron reduction from a multicomponent silicate melt during sparging. Message 2. A reducing agent is a mixture of $\mathrm{H}_{2}-\mathrm{H}_{2} \mathrm{O}$. News of universities. Ferrous metallurgy. 2018. Vol.61. No.10. P.794-800. (russian)

[7] M.R. Rusakov, G.V. Vostrikov, L.N. Pinin, E.A. Samsonov, E.A. Sadovnikova. New depletion methods for converter and furnace slags using gaseous and liquid reducing agents and electricity.

Pyrometallurgical processes and methods of analysis in nickel and cobalt technology. Sat scientific tr. Gipronickel. Leningrad. 1979. P.8-15. (russian) 
[8] M.R. Rusakov. Depletion of slag melts by purging with reducing gases. Non-ferrous metals. 1985. No.3. P.40-42. (russian)

[9] A.N. Fedorov, A.A. Malevsky, G.V. Idenbaum and others. The behavior of non-ferrous metals in the recovery of deeply oxidized slags. Non-ferrous metals. 1995. No.11. P.7-10. (russian)

[10] A.S. Fialkov. Carbon, interlayer compounds and composites based on it. Moscow: Aspect-press. 1997. 718p. (russian)

[11] A.V. Stepanov. Production of hydrogen and hydrogen-containing gases. Kiev: Naukova Dumka. 1982. 312p.

[12] A.N. Kutepov, T.I. Bondareva, T.I. Berengarten. General chemical technology. Moscow: Academkniga. 2004. 405p. (russian)

[13] V.S. Arutyunov, O.V. Krylov. Oxidative methane conversion. Successes chemistry. 2005. Vol.74. No.12. P.1216-1245. (russian)

[14] V.S. Arutyunov. Oxidative conversion of natural gas. Moscow: Krasand. 2011. 590p. (russian)

[15] A.V. Stepanov. Production of hydrogen and hydrogen-containing gases. Kiev: Naukova Dumka. 1982. 312p.

[16] I.F. Kurunov, N.A. Savchuk. The state and prospects of homeless iron metallurgy. Moscow: Chermetinformatsiya. 2002. 198p. (russian)

[17] B. Bondarenko, V. Shapovalov, N. Garmash. Technology and theory of coke-less metallurgy. Kiev: Science Thought. 2003. 536p.

[18] A.A. Pugacheva, G.N. Razin. Plasma chemical processing of carbon-containing compounds. Advances in chemistry and chemical technology. 2008. Vol.22. No.6. P.65-70. (russian)

[19] A. Pushkarev, Ai-Ming Zhu, Hiao-Song Li, R.V. Sazonov. Conversion of methane in low-temperature plasma. High Energy Chemistry. 2009. Vol.43. No.3. P.202-208. (russian)

[20] F.G. Rutberg, A.N. Bratsev, V.A. Kuznetsov and others. Production of synthesis gas by methane conversion in a plasma of water vapor and carbon dioxide. Letters in ZhFH. 2014. Vol.40. Iss.17. P.110. (russian)

[21] Z.G. Sharafutdinov, V.O. Konstantinov, V.I. Fedoseev, V.G. Schukin. Conversion of natural and associated petroleum gas in a cold electron beam plasma. Applied Physics. 2017. No.2. P.13-18. (russian)

[22] Patent 2639396 RU. The method of pyrometallurgical processing of oxidized nickel orehttp: //wwwl.fips.ru/fips_servl/BiEndhttp://wwwl.fips.ru/fips_servl/AbStart. Vusikhis A.S., Leontyev L.I., Selivanov E.N., Podgorodetsky G.S. Appl. 01/10/2017; publ. 12/21/2017. Bul. No.36.

[23] A.N. Morozov. Modern steel production in arc furnaces. Chelyabinsk: Metallurgy. 1987. 175p. (russian) 